\title{
Apologies abound: advances in adverse-event disclosure
}

$\mathrm{C}$ anadian physicians seeking to improve communication with patients who have been harmed are getting plenty of assistance.

Ontario late last year became the fourth province to unveil apology legislation, while the Canadian Patient Safety Institute and the Canadian Medical Protective Association released guidelines for disclosing harm to patients.

The measures are complementary, since the intent of the guidelines is to "remove concerns about potential legal liability and other sanctions" when health professionals tell patients about harm, says Brent Windwick, chair of the Institute's legal and regulatory affairs advisory committee.

Windwick warns that apology legislation does not remove the need for effective and thorough training for health professionals about how to tell patients about adverse events. But it will "remove a significant source of hesitation" about speaking to patients who have suffered harm.

British Columbia was the first province to pass an apology act, in 2006, with Manitoba and Saskatchewan following suit in 2007.

But it's too early - and may never be possible - to credit Canadian legislation with having a clear impact on the number of medical-legal cases, says Dr. William Tucker, president of the protective association.

Expressions of sympathy can improve relations, he adds. "Families feel better if there is an acknowledgement that there has been an adverse event" and, after expressing regret and sympathy, it may be easier for a physician to carry on the therapeutic relationship.

If passed, Ontario's legislation will "promote accountability, transparency and patient safety by allowing open and frank discussions," according to a spokesman for the province's Ministry of the Attorney General.

Canadian apology legislation is broader than legislation in some Australian and US states where laws deal only with "expressions of regret" and stop short of addressing the issue of apology, says Windwick.

At its 2008 annual meeting, the Canadian Medical Association voted to lobby governments for appropriate apology legislation in all Canadian jurisdictions. - Ann Silversides, CMAJ

DOI:10.1503/cmaj.090066

\section{US biovigilance network to track donor-derived infections}

$\mathrm{T}$ he United States has begun rolling out a "national biovigilance network" to track donorderived infections transmitted during organ transplants and blood transfusions.

The web-based network will collect data on deaths and complications stemming from donated blood, organs and

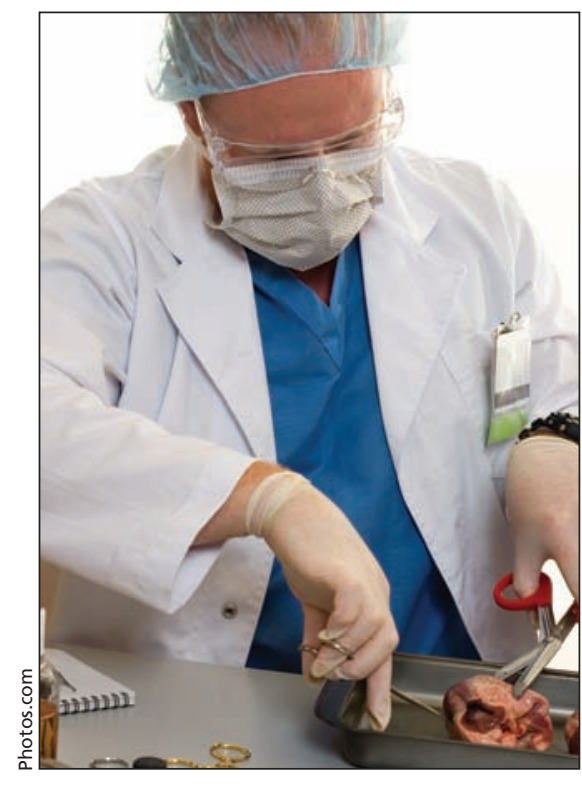

A doctor examines a kidney. human tissue and subsequently notify hospitals about potential infections.

Jointly developed by a coalition that includes the United States Centers for Disease Control and Prevention, the United Network for Organ Sharing and the American Association of Blood Banks, the network is being piloted in several facilities this spring with an eye toward expansion into a national network later this year.

With a single donor's organs and tissues often reaching multiple recipients, a tracking system has become essential, says Dr. Matthew Kuehnert, director of the Centers for Disease Control and Prevention's Office of Blood, Organs and Other Tissue Safety. "This system would allow doctors to check on all the other transplants from that donor before the surgery proceeds. This can be used to observe if there have been any adverse effects from any transplant from that one donor. This will serve a dual function of both surveillance and intervention."

The system focuses on 4 elements: blood donor safety, blood recipient safety, prevention of adverse effects in organ and tissue transplants, and cellular therapy.
The network's main goal is to "effectively connect the eye, tissue and organ communities through communication of essential clinical information," says Gloria Taylor, standards administrator and ethicist for the United Network for Organ Sharing, which over the past 3 years has been developing a separate Transplantation Transmission Sentinel Network for detecting, communicating, tracking and preventing transmission of infections from organ, tissue and cornea donors.

While developing the biovigilance system, organizers contacted other countries, including Canada, for assistance. "Canada has an excellent system, and we learned a lot from them," says Kuehnert.

The increased precautions could cause a slowdown of organ transfers across the US-Canada border, potentially increasing patient wait times in Canada, according to a Health Canada official. In turn, that could prompt some desperate patients to accept higher risk organs than is recommended. - David Manly, Ottawa, Ont.

DOI:10.1503/cmaj.090064 